\title{
Fungsionalisasi ADR dan Penyelesaian Sengketa Lingkungan Hidup
}

\author{
R.F.Saragih
}

\begin{abstract}
The resolution of the environmental disputes on the Act No. 23, 1967 of the Environmental Management is usually conducted by two ways: incourt and outside court. Since, as widely known, the settlement of the disputes in court is often belated, the settlement outside court is an alternative to anticipate the belatedness, It is often known as the Altemative Dispute Resolution (ADR). Based on this argument, an attempt to function the $A D R$ in the environmental dispute resolution becomes urgently required, primarily in terms of the environmental disputes in civil cases.
\end{abstract}

\section{Pendahuluan}

Konflik atau sengketa yang disebabkan oleh proses pembangunan merupakan fenomena yang menonjol, terutama dalam dekade-dekade terakhir ini. Gejala semacam ini dapat dijumpai di negara-negara berkembang yang sedang melakukan proses pembangunan termasuk juga Indonesia. Kondisi ini merupakan konsekuensi logis atas pilihan strategi pembangunan yang umumnya ditempuh oleh negara-negara berkembang pasca Perang Dingin II melalui konsep Industrialisasi.'

Konsep industrialisasi pada dasarnya mempunyai tujuan utama mengejar keuntungan

yang setinggi-tingginya, sedangkan kepedulian kalangan industri terhadap lingkungan hidup biasanya sangat tipis. Kerusakan dan pencemaran lingkungan yang disebabkan oleh limbah industri adalah masalah yang paling banyak diketemukan di sentra-sentra industri/pabrik harus menanggung akibatnya. Jika mereka menyadari akibat dari kerusakan dan pencemaran lingkungan, maka tidak menutup kemungkinan akan menimbulkan konflik antara pelaku dan penanggung akibat tersebut.

Sebagai upaya penyelesaian terhadap konflik atau sengketa lingkungan hidup

'Hadimulyo. 1997. Mempertimbangkan ADR Kajian Altematif Penyelesaian Sengketa di Luar Peradilan. Jakarta: Elsam. Him.1. 
diperlukan aturan hukum yang jelas dan tegas. Dengan adanya hukum ini rasa keadilan dań kepastian hukum bagi semua pihak akan dapat diwujudkan. Selain itu hukum harus mampu pula berperan sebagai sarana pembangunan dengan peran sebagai agent of development atau agent of change yang dapat diorientasikan kepada pola pembangunan yang berwawasan lingkungan (sustainable development).

Saat ini Indonesia telah menyempurnakan UU No. 4 Tahun 1982 tentang Ketentuanketentuan Pokok Lingkungan Hidup dengan UU No. 23 Tahun 1997 tentang Pengelolaan Lingkungan Hidup. ${ }^{2}$ Penyempumaan peraturan perundang-undangan dimaksudkan salah satunya sebagai upaya melaksanakan perigelolaan lingkungan hidup untuk melestarikan dan mengembangkan kemampuan lingkungan hidup yang serasi, selaras, dan seimbang guna menunjang terlaksananya pembangunan berkelanjutan yang berwawasan lingkungan hidup.

UUPLH melakukan pengaturan lingkungan hidup dari aspek hukum administrasi, hukum perdata, hukum pidana, dan upaya penyelesaian sengketa lingkungan hidup di luar pengadilan. Khusus berkaitan dengan penyelesaian sengketa di luar lembaga peradilan dalam wacana hukum lebih dikenal dengan sebutan lembaga Alternatif Dispute Resolution (ADR). ${ }^{3}$ Lembaga ini sudah dikenalkan sejak adanya UULH dan dalam UUĹPH mengalami perluasan baik menyangkut pihak ataupun bentuk ADR seridiri. Landasan' hukum yang digunakan untuk penerapan $A D R$ di bidang lingkungan hidup didasarkan' sebelumnya pada Pasal 20 ayat (2) UULH dan saat ini telah diganti berdasarkan Pasal 31 sampai dengan Pasal 33 UUPLH.

Artikel dimaksudkan untuk mengintroduksi sejauhmana fungsionalisasi lembaga ADR dalam penyelesaian sengketa lingkungan hidup sehingga tujuan melestarikan lingkungan hidup yang diinginkan UUPLH dapat tercapai.

\section{Pengertian dan Perkembangan Lembaga ADR}

Untuk memperoleh gambaran umum tentang apa yang disebut ADR, George Applebey dalam tulisannya An Ovenview of Alternative Dispute Resolution ${ }^{4}$ dengan merujuk pendapat Liebermann dan Hendry, berpendapat bahwa ADR pertama-tama adalah merupakan suatu eksperimen untuk mencari; 1). Model-model baru dalam penyelesaian sengketa; 2). Penerapanpenerapan baru terhadap metode-metode lama; 4). Forum-forum baru bagi penyelesaian sengketa; dan 5). Penekanan yang berbeda dalam pendidikan hukum.

2UU No. 4 Tahun 1982 tentang Ketentuan-ketentuan Pokok Lingkungan Hidup selanjutnya disebut UULH dan UU No. 23 Tahun 1997 tentang Pengelolaan Lingkungan Hidup selanjutnya disebut UUPLH.

${ }^{3}$ Alternatif Dispute Resolution selanjutnya disebutADR.

"Nandang Sựtrisno. "Dasar-dasar Penyelésaian Sengketa Alternatif." Makalah yang disampaikan dalam Pelatihan Alternative Dispute Resolution (ADR) yang diselenggarakan oleh Fakultas Hukum UII bekerjasama dengan The Asia Foundation. Yogyakarta. $19 \mathrm{~s} / \mathrm{d} 22$ Agustus 1999. HIm. 3-4. 
Pendapat yang lebih spesifik mengenai pengertian ADR ini juga dapat melihat kepada pendapat yang disampaikan oleh Philip D. Bostwick yang menyatakan bahwa ADR merupakan serangkaian praktik dan teknikteknik hukum yang ditujukan untuk; a). memungkinkan sengketa-sengketa hukum diselesaikan di luar pengadilan untuk keuntungan atau kebaikan para pihak yang bersengketa sendiri; $b$ ). mengurangi biaya dan keterlambatan kalau sengketa tersebut diselesaikan melalui litigasi konvensional; c). mencegah agar sengketa-sengketa hukum tidak dibawa ke pengadilan.

Pendapat lainnya mengatakan, bahwa ADR adalah sebuah konsep yang mencakup berbagai bentuk penyelesaian sengketa selain dari proses peradilan melalui cara-cara yang sah menurut hukum, baik berdasarkan pendekatan konsensus atau tidak berdasarkan pendekatan konsensus. ${ }^{5}$

Berdasarkan berbagai pendapat tersebut, maka dapat dijelaskan bahwa pengertian ADR merupakan mekanisme penyelesaian sengketa alternatif di luar lembaga peradilan (non-litigasi) dengan menggunakan pola pendekatan konsensus maupun non-konsensus dengan maksud untuk mempercepat penyelesaian sengketa serta memperingan biaya perkara.

Perkembangan ADR sebenarnya tidak terlepas dari kondisi empirik lembaga peradilan yang banyak memberikan kesan dalam setiap penyelesaian sengketa berjalan dengan berbelit-belit, memakan waktu yang lama, serta biaya yang sangat tinggi.

Anggapan ini sudah terjadi sejak Abad 18 ketika Voltaire berkata: "I was ruined but twice - once when I gained a lawsuit, and once when I lost one". Kemudian Abraham Lincoln menasihatkan: "Hindarilah berperkara di pengadilan, sedapat mungkin ajaklah tetangga-tetangga anda untuk berkompromi. Tunjukan kepada mereka betapa orang yang menang berperkara seringkali merupakan orang yang kalah."

Jadi, jelaslah bahwa kehadiran lembaga ADR adalah dalam upaya mencari pola penyelesaian sengketa yang sifatnya efektif dan efesien dan saat ini model-model ADR sudah berkembang begitu pesat.

Untuk konteks Indonesia model penyelesaian sengketa alternatif sudah mulai dikembangkan dan ini dapat dilihat dengan adanya pengakomodiran model-model sengketa alternatif dalam beberapa peraturan perundang-undangan. Salah satu contohnya misalnya dalam UUPLH.

\section{Bentuk Penyelesaian Sengketa Alternatif}

ADR yang selama ini dikenal pada prinsipnya mempunyai berbagai macam bentuk. Adapun bentuk-bentuk ADR tersebut di antaranya adalah sebagai berikut:

1. Negosiasi ${ }^{6}$

Negosiasi merupakan sarana bagi pihak-pihak yang bersengketa untuk

\footnotetext{
${ }^{5}$ Hadimulyo. Op. Cit. HIm. 2.
}

'Zairin Harahap. "ADR Sebagai Alternatif Penyelesaian Sengketa Lingkungan." Disampaikan dalam diskusi Alternative Dispute Resolution. Diselenggarakan oleh Pusdiklat FHUll. Yogyakarta tanggal 5 Maret 1999. HIm. 6. 
melakukan penyelesaiannya tanpa keterlibatan pihak ketiga yang tidak berwenang mengambil keputusan (mediasi) maupun pihak ketiga yang berwenang mengambil keputusan (arbitrase). Secara umum teknik negosiasi dapat dibagi menjadi 2 (dua), yakni; teknik negosiasi yang kompetitif dan teknik negosiasi yang kooperatif.

Teknik negosiasi yang kompetitif seringkali diistilahkan dengan teknik negosiasi yang bersifat alot (tough) di mana unsur-unsur yang menjadi ciri seorang negosiator kompetitif adalah sebagai berikut:

a. Mengajukan permintaan awal yang tinggi pada awal negosiasi;

b. Menjaga tuntutan agar tetap tinggi sepanjang proses negosiasi dilangsungkan;

c. Konsesi diberikan sangat langka/ jarang atau terbatas;

d. Secara psikologis perunding yang menggunakan teknik ini menganggap perunding lain sebagai musuh atau lawan;

e. Seringkali menggunakan yang berlebihan, kasar, menggunakan ancaman, bluff, dan melemparkan tuduhan-tuduhan untuk menciptakan ketegangan dan tekanan terhadap pihak lawan.
Teknik negosiasi yang kooperatif merupakan kebalikannya. Teknik ini menganggap pihak lawan (oposing party) bukan sebagai musuh, namun sebagai mitra kerja mencari common ground. Para pihak berkomunikasi untuk menjajagi kepentingan dan nilai-nilai bersama (shared interest and vaules) dengan menggunakan rasio dan akal sehat, sehingga penyelesaian dilakukan berdasarkan analisis objektif sebagai upaya membangun atmosfir yang positif dan saling percaya.

2. Konsiliasi

Di dalam masyarakat istilah damai (konsiliasi) dalam menyelesaikan suatu urusan atau masalah seringkali mempunyai konotasi negatif, yaitu mempermudah proses penyelesaian dengan jalan di luar prosedur yang ditetapkan dengan memberikan imbalan sejumlah uang kepada pihak-pihak yang terlibat dalam proses' tersebut. $^{\text {? }}$

Pengertian konsiliasi adalah penyelesaian sengketa yang dilakukan dalam suasana kekeluargaan (friendly). ${ }^{8}$ Syarat utama dalam menggunakan cara ini adalah bahwa sejak awal para pihak harus telah menyadari hak-hak dan kewajibannya, serta telah dapat memahami keprihatinan masing-masing mengenai masalah yang disengketakan.

7Marsudi Triatmodjo. "Altematif Penyelesaian Sengketa Lingkungan (Industrialisasi v Masyarakat." Disampaikan dalam seminar Industrialisasi dan Dampaknya Terhadap Lingkungan Hidup. Diselenggarakan oleh LOKTIKX, KN Kimia-FMIPA'UGM. Yogyakarta tanggal 28 Maret 1996. HIm 7.

${ }^{8}$ Henry Campbell Black. 1990. Black's Law Dictionary. St. Paul Minn: West Publiching Co.Hlm.289-290. 


\section{Mediasi}

Mekanisme penyelesaian sengketa lingkungan dengan cara ini telah banyak digunakan di negara-negara industri maju, seperti Amerika, Kanada, dan Jepang. Menurut Grenville-Wood, cara ini pada pokoknya diartikan sebagai suatu proses penyelesaian sengketa dengan bantuan pihak ketiga yang netral dalam upaya negosiasi penyelesaian sengketa tersebut. Dengan cara ini, para pihak mencari seorang atau tim mediator dengan cara seperti mencari pengacara yang dapat diterima oleh semua pihak. ${ }^{9}$

Seorang mediator pada prinsipnya akan membantu para pihak yang bersengketa untuk menyepakati suatu kesepakatan yang berorientasi ke depan sesuai kebutuhan dan memenuhi rasa keadilan. Mediator tidak memiliki kewenangan campur tangan untuk memutuskan dan menentukan hasil akhir kesepakatan karena para pihak yang bersengketa itu sendiri yang harus melakukannya. ${ }^{10}$

Aspek yang paling penting dalam proses mediasi adalah adanya kesediaan para pihak untuk berunding menyelesaikan sengketa secara jujur dan dapat diterima semua pihak. Dengan mengadakan perundingan secara jujur ini, para pihak akan saling mengetahui hak-hak dan kewajibannya, dengan demikian akan memahami keprihatinan masing-masing.

4. Arbitrase"

Arbitrase merupakan mekanisme penyelesaian sengketa dengan bantuan pihak ketiga yang netral. Namun, dibanding ketiga mekanisme tersebut, pihak ketiga bertindak sebagai "hakim" yang diberi kewenangan penuh oleh para pihak untuk menyelesaikan sengketa. Oleh karena itu ia berwenang mengambil keputusan (award) yang bersifat final dan mengikat (final and binding).

Dari berbagai macam bentuk ADR ini, maka keberadaan bentuk-bentuk itu sendiri dapat saja mengalami modifikasimodifikasi model yang ini disesuaikan dengan kebutuhan situasi dan kondisi pada saat penyelesaian sengketa itu sendiri.

\section{Pengaturan ADR dalam UULH dan UUPLH}

Sengketa lingkungan hidup yang sering muncul di permukaan adalah kasus-kasus yang berkaitan dengan pencemaran dan perusakan lingkungan hidup, dan juga konflik kepentingan atas sumber daya alam (limbah industri, bahan beracun dan berbahaya, air, dan juga hak adat/ulayat atas hutan, dan lain sebagainya). Karena itu peraturan perundang-

${ }^{9}$ Koesnadi Hardjasoemantri. 1994. Hukum Tata Lingkungan. Ed. Keenam. CetKesebelas. Yogyakarta: Gajah Mada University Press. HIm. 374.

${ }^{10}$ Ahmad M. Ramli. 1999. Tanggapan Atas Rancangan Undang-Undang tentang Penyelesaian Sengketa. Makalah disampaikan pada seminar Sosialisasi atas RUU APS. Diselenggarakan oleh Departemen Kehakiman RI. Jakarta. Him. 2.

${ }^{11}$ Nandang Sutrisno. Op. Cit. HIm. 7. 
undàngan yang dàpat menjadi rujukan atau titik tolak penyelesaian sengketa lingkungan . hidup akan diusahakan pelacakannya.

Pasal 20 ayat (2) UULH beserta penjeläsañnya ' menyatakan bahwa penyelesaian sengketa lingkungan hidup dilaksanakan terlebih dahulu melalui mekanisme pembentukan tim tripihak, yang terdiri dari pencemar atau kuasanya, penderita atau kuasanya, dan unsur pemerintah. Apabila kesepakatan dalam tim tripihak tidak tercapai, maka sengketa tersebut dibawa ke pengadilan.

Dari ketentuan tersebut dapat disimpulkan bahwa pembentukan tim tripihak adalah mandatory, suatu keharusan. Dengan demikian sengketa lingkungan hidup tidak dapat langsung diajukan ke pengadilan, akan tetapi harus melaiui penyelesaian dalam tripihak dulu.

Dengan adanya lembaga mediasi sebagai bagian dari lembaga yang ada dalam ADR, di sana kedudukan dan fungsi mediator bertindak sebagai pihak yang netral dan bersifat memfasilitasi berbagai alternatif penyelesaiàn sengketa. Seandainya salah satu alternatif penyelesaian sengketa yang diajukan oleh mediator disetujui oleh kedua belah pitiak, maka selesailah tugas mediator dan untuk untuk jasanya itu mediator mendapat imbalan.

Pada praktiknya, pembentukan tim tripihak yang dimediatori pemerintah sering tidak dapat berjalan sebagaimana mestinya. Hal ini disebabkan oleh faktor ketidaknetralan dari pihak pemerintah. Pada masa rejim Orde Baru kultur birokrasi yang ada telah melahirkan bentuk korupsi, kolusi, dan nepotisme. Kultur ini juga berlaku dalam upaya penyelesaian sengketa lingkungan hidup di luar pengadilan sementara dalam UULH tidak memungkinkan. menjadikan pihak lainnya untuk dapat menjadi mediator.
-Atas dasar pertimbangan dan realitas tersebut, maka berdasarkan UUPLH pola penyelesaian lingkungan hidup di luar pengadilan diperluas makna maupun penentuan pihak mediator. Pasal 30 ayat (1) UUPLH menyatakan bahwa penyelesaian sengketa lingkungan hidup dapat ditempuh melalui pengadilan atau di luar pengadilan berdasarkan pilihan sukarela para pihak yang bersengketa. Artinya penyelesaian sengketa lingkungan hidup tidak harus melalui upaya di luar pengadilan lebih dahulu, sebagaimana tertuang dalam Pasal 20 ayat (2) UULH beserta penjelasannya.

Pasal 31 UUPLH menyatakan bahwa penyelesaiaan sengketa lingkúngan di luar pengadilan diselenggarakan untuk mencapai kesepakatan mengenai bentuk dan besamya ganti rugi dan atau mengenai tindakan tertentu guna menjamin tidak akan terjadinya atau terulangnya dampak negatif terhadap lingkungan.

Penjelasan pasal ini menyatakan bahwa penyelesaian sengketa lingkungan hidup melalui perundingan di luar pengadilan dilakukan secara sukarela oleh para pihak yang berkepentingan, yaitu para pihak yang mengalami kerugian dan mengakibatkan kerugian, instansi pemerintah yang terkait dengan subjek yang mempunyai kepedulian terhadap pengelolaan lingkungan hidup.

Tindakan tertentu yang dimaksud dalam pasal ini adalah sebagai upaya memulihkan fungsi lingkungan hidup dengan memperhatikan nilai-nilai yang hidup dalam masyarakat setempat. Perlu diperhatikan tentang penentuan besarnya kerugian. Hal ini dapat diserahkan kepada tim ahli untuk menghitúngnya. Dèmikian pula tentang besarnya biaya yang diperlukan untuk 
memulihkan lingkungan hidup dapat diserahkan perhitungannya kepada tim ahli.

Pasal 32 UUPLH menyebutkan bahwa penyelesaian sengketa lingkungan hidup di luar pengadilan sebagaimana dimaksud dalam Pasal 31 UUPLH dapat digunakan jasa pihak ketiga, baik yang tidak memiliki kewenangan mengambil keputusan maupun yang memiliki kewenangan mengambil keputusan, untuk membantu menyelesaikan sengketa lingkungan hidup.

Penjelasan pasal ini menyatakan bahwa untuk melancarkan jalannya perundingan di luar pengadilan, para pihak yang berkepentingan dapat meminta jasa pihak ketiga netral yang dapat berbentuk:

a. Pihak ketiga netral yang tidak memiliki kewenangan mengambil keputusan. Pihak ketiga netral ini berfungsi sebagai pihak yang memfasilitasi para pihak yang berkepentingan sehingga dapat dicapai kesepakatan.

1. Disetujui oleh para pihak yang bersengketa;

2. Tidak memiliki hubungan keluarga dan/atau hubungan kerja dengan salah satu pihak yang bersengketa;

3. Memiliki keterampilan untuk melakukan perundingan atau penengahan;

4. Tidak memiliki kepentingan terhadap proses perundangan maupun hasilnya.

b. Pihak ketiga netral yang memiliki kewenangan mengambil keputusan berfungsi sebagai arbiter, dan semua putusan arbitrase ini bersifat tetap dan mengikat para pihak yang bersengketa.

Formulasi penjelasan Pasal 31 UUPLH ini membuktikan sifat mengikatnya penjelasan karena penafsiran otentiknya, sedangkan dalam batang tubuh mengikat karena sifat normatifnya.

Pasal 31 ayat (1) UUPLH menyatakan bahwa Pemerintah dan/atau masyarakat dapàt membentuk lembaga penyedia jasa pelayanan penyelesaian sengketa lingkungan hidup yang bersifat bebas dan tidak berpihak

Penjelasan ayat ini menyatakan bahwa lembaga penyedia jasa penyelesaian sengketa lingkungan hidup ini dimaksudkan sebagai suatu lembaga yang mampu memperlancar pelaksanaan mekanisme pilihan penyelesaian sengketa dengan mendasarkan pada prinsip ketidakberpihakan dan profesionalisme. Lembaga penyedia jasa yang dibentuk oleh pemerintah dimaksudkan sebagai pelayanan publik.

Pasal 31 ayat (2) menyatakan bahwa ketentuan mengenai penyedia jasa pelayanan penyelesaian sengketa lingkungan hidup diatur lebih lanjut dengan Peraturan Pemerintah. Peraturan Pemerintah tentang hal ini diperlukan agar diperoleh pembakuan (standarisasi) lembaga penyedia jasa tersebut.

Mengingat penyelesaian sengketa lingkungan hidup mempunyai sifat-sifat tersendiri, yang diperoleh melalui program yang mengarah kepada kualifikasi.

\section{Fungsionalisasi ADR dalam Penyelesaian Sengketa Lingkungan Hidup}

Salah satu faktor penyebab dari difungsikannya lembaga ADR dalam penyelesaian sengketa semuanya ini tidak lepas dari sistem peradilan yang cenderung dalam penyelesaian sengketa-sengketanya lebih banyak memakan waktu, biaya serta cenderung berbelit-belit. 
Fungsionalisasi ADR dalam pẹnyelesaian sengketa lingkungan hidup dapat dilakukan melalui dua cara, yakni; pertama melalui Out of Court ADR dan keduanya melalui Court of Connected ADR. Out of Court ADR adalah upaya penyelesaian sengketa lingkungan hidup dengan cara benar-benar di luar lembaga peradilan. Sedangkan cara Court of Connected ADR merupakan upaya penyelesaian sengketa lingkungan hidup melalui lembaga ADR yang dihubungkan dengan lembaga peradilan.

Dari kedua cara ini yang lebih memungkinkan untuk diterapkan di Indonesia adalah upaya out of court $A D R$, karena cara pertama ini memang sangat efektif dalam mengurangi beban perkara di pengadilan. Sebagai contoh dalam kasus pencemaran sungai antara PT. Semarang Diamond Chemical (anak perusahaan dari PT. Bintaro Dharma yang berkongsi dengan Mitsubishi dan Showa Chemical dari Jepang) dan penduduk Dukuh Tapak, Semarang yang digambarkan oleh Santoso dan Hutapea. ${ }^{12}$ Walaupun dalam pelaksanaan kesepakatan yang dicapai pada tanggal 29 Agustus 1991 tersebut tidak berjalan dengan mulus, secara umum model mediasi (mungkin lebih tepat jika dikatakan "quasi mediasi" karena ada keterlibatan unsur pemerintah) yang digunakan di Dukuh Tapak ini dapat dikatakan berhasil.

Indikator keberhasilan dapat dilihat dari kesepakatan yang dicapai oleh para pihak, di antaranya meliputi: a). ganti rugi; b) upaya pengendalian pencemaran; $c$ ) upaya rehabilitasi; d) tanggung jawab sosial industri terhadap masyarakat, sebagai konsekuensi dari prinsip koeksistensi antara industri dan masyarakat; e) perombakan perijinan usaha dari para industri dengan-menerapkan syarat pengendalian pencemaran tambahan; $f$ ) mekanisme pemantauan pasca kesepakatan dengan cara melibatkan masyarakat dan LSM.

Keberhasilan ini tidak terlepas dari keseriusan dari Pemerintah Daerah dalam menyelesaikan kasus yang telah berjalan 14 tahun tersebut, proses kesepakatan yang tercapai hanya dalam waktu 85 hari, serta pembiayaan yang relatif murah jika dibandingkan dengan cara litigasi, bahkan masyarakat korban pencemaran Tapak tidak dibebani biaya karena pembiayaannya diambil dari APBD Kotamadya Semarang.

Kasus di atas merupakan salah satu kasus yang dapat diselesaikan melalui lembaga ADR meskipun penyelesaian kasus masih memakai UULH. Tetapi setidaknya dengan gambaran ini ada semacam harapan' fungsi dan peran lembaga ADR akan mampu memberikan kontribusi yang positif dalam penyelesaian sengketa lingkungan hidup, terlebih jika melihat kepada UUPLH kesempatan dalam mengoptimalisasikan lembaga ADR ini sangat besar dan luas.

Kemudian untuk upaya Court of Connected $A D R$, hal ini masih belum memungkinkan disebabkan kondisi lembaga peradilan Indonesia masih menyimpan sejumlah permasalahan, di antaranya masih banyaknya perkara yang menumpuk dan

${ }^{12}$ Mas Achmad Santosa \& Anthony LP Hutapea. 1992. Sebuah Pengalaman: Mendayagunakan Mekanisme Alternatif Penyelesaian Sengketa Lingkungan (MAPS) di Indonesia. Jakarta: WALHIUSAID. HIm. 3-6. 
belum diselesaikan bila cara kedua ini dipaksa untuk dipakai, maka penumpukan perkara itu akan semakin bertambah.

Strategi lain dalam upaya fungsionalisasi lembaga ADR di Indonesia seperti diketahui akhis-akhir ini pemerintah telah membentuk Tim ADR yang diketuai oleh Menteri Menkumdang, bekerjasama dengan Asia Foundation yang tugasnya mempersiapkan pelaksanaan ADR dan lembaga penyedia jasa penyelesaian sengketa lingkungan hidup.

Di samping itu pemberian mata kuliah ADR di Fakultas Hukum menjadi sangat urgen dalam upaya fungsionalisasi ADR dalam penyelesaian sengketa lingkungan hidup. Karena dengan diberikannya mata kuliah ADR di Fakultas Hukum, maka dapat tersedia tenaga-tenaga profesional yang bekerja sebagai penyedia jasa penyelesaian sengketa di bidang perdata dan perkara lingkungan.

\section{Simpulan}

Penyelesaian sengketa lingkungan hidup harus dilihat kasus per kasus. Penggunaan cara litigasi atau memilih berbagai penyelesaian sengketa alternatif (ADR) sifatnya situasional, karena sengketa lingkungan yang terjadi seringkali sarat dengan berbagai kepentingan.

Penyelesaian sengketa lingkungan hidup perlu dilakukan secara hati-hati dan bijaksana. Selesainya sengketa lingkungan hidup yang terjadi pada suatu masyarakat bukan merupakan tujuan akhir, tujuan akhirnya adalah terwujudnya kesejahteraan seutuhnya dari masyarakat yang bersangkutan.

Untuk mencapai semua itu, salah satunya melalui fungsionalisasi ADR dalam penyelesaian sengketa lingkungan hidup dalam bentuk Out of Court ADR. Model ini dipilih oleh karena dengan cara ini proses penyelesaian sengketa lingkungan hidup dapat berjalan dengan cepat serta dapat memuaskan semua pihak.

\section{Daftar Pustaka}

Black, Henry Campbell. 1990. Black's Law Dictionary. St. Paul Minn: West Publiching Co.

Hadimulyo. 1997. Mempertimbangkan ADR Kajian Alternatif Penyelesaian Sengketa di Luar Peradilan. Jakarta: Elsam.

Harahap, Zairin. "ADR Sebagai Alternatif Penyelesaian Sengketa Lingkungan." Disampaikan dalam diskusi Alternative Dispute Resolution. Diselenggarakan oleh Pusdiklat FH UII. Yogyakarta tanggal 5 Maret 1999.

Hardjasoemantri, Koesnadi. 1994. Hukum Tata Lingkungan. Ed. Keenam. Cet Kesebelas. Yogyakarta: Gajah Mada University Press.

Ramli, Ahmad M. 1999. Tanggapan Atas Rancangan Undang-Undang tentang Penyelesaian Sengketa. Makalah disampaikan pada seminar Sosialisasi atas RUU APS. Diselenggarakan oleh Departemen Kehakiman RI. Jakarta.

Sutrisno, Nandang. "Dasar-dasar Penyelesaian Sengketa Alternatif." Makalah yang disampaikan dalam Pelatihan Alternative Dispute Resolution (ADR) yang diselenggarakan oleh Fakultas Hukum UII bekerjasama dengan The Asia Foundation. Yogyakarta. $19 \mathrm{~s} / \mathrm{d} 22$ Agustus 1999. 
Santosa, Mas Achmad \& Anthony LP Hutapea. 1992. Sebuah Pengalaman: Mendayagunakan Mekanisme Alternatif Penyelesaian Sengketa Lingkungan (MAPS) di Indonesia. Jakarta: WALHI USAID.

Triatmodjo, Marsudi. "Alternatif Penyelesaian Sengketa Lingkungan (Industrialisasi v Masyarakat." Disampaikan dalam

seminar Industrialisasi dan Dampaknya Terhadap Lingkungan Hidup. Diselenggarakan oleh LOKTIK $X$, KN Kimia-FMIPA UGM. Yogyakarta tanggal 28 Maret 1996.

Undang-Undang No. 4 Tahun 1982 tentang Lingkungan Hidup.

Undang-Undang No. 23 Tahun 1997 tentang Pengelolaan Lingkungan Hidup.

将妨 